\title{
Behandling av infantilt hemangiom med propanolol
}

\author{
Sammendrag \\ Bakgrunn. Et infantilt hemangiom er \\ en godartet karderivert tumor. 8-12\% \\ av alle barn rammes. I flere nyere \\ artikler beskrives effekt av betablokke- \\ ren propanolol i behandlingen. Vi brin- \\ ger her en kasuistikk og gir en oversikt \\ over dagens litteratur.
}

Materiale og metode. Artikkelen er bygd på ikke-systematisk litteratursøking i PubMed og vår egen erfaring med bruk av propanolol hos en pasient med periokulært infantilt hemangiom.

Resultater. Det var rask effekt av propanololbehandlingen hos vår pasient, med klinisk respons etter få dager. I artikler publisert i internasjonale tidsskrifter beskrives respons innen 24-48 timer, med reduksjon i størrelse og fargeforandringer av hemangiomene. Vår erfaring er på linje med det som er rapportert ellers i medisinsk litteratur. Kunnskapen er basert på observasjon av små grupper pasienter. Det finnes ingen prospektive, kontrollerte studier.

Fortolkning. Propanolol synes å være effektiv behandling av hemangiomer hos barn. Det trengs kontrollerte studier for å dokumentere optimal dosering, monitorering, bivirkninger og varighet av behandling. Behandlende lege bør alltid være oppdatert på de nyeste retningslinjer.
Kjetil K.S. Guldbakke

kjetil.guldbakke@stolav.no

Ole-Martin Rørdam

Theis Huldt-Nystrøm

Helle Kathrine Hanssen

Hudavdelingen

Finn Høivik

Barne- og ungdomsklinikken

St. Olavs hospital

7006 Trondheim

Infantile hemangiomer er godartede karderiverte tumorer. De opptrer hos $8-12 \%$ av alle barn (1). Vanligvis kommer de til syne $\mathrm{i}$ løpet av de første ukene etter fødselen. Behandling må vurderes hvis hemangiomet truer vitale funksjoner som syn og luftveier eller det er systemisk affeksjon. I flere nyere artikler er det beskrevet effekt av betablokkeren propanolol for denne pasientgruppen $(1,2)$. Vi gir her en oversikt over dagens litteratur omkring behandling av infantilt hemangiom med dette midlet og kommer med et eksempel fra vår kliniske praksis.

\section{Materiale og metode}

Grunnlaget for artikkelen er et ikke-systematisk litteratursøk i PubMed med et skjønnsmessig utvalg av artikler basert på forfatternes kliniske erfaring på feltet.

\section{En sykehistorie}

Pasienten. En seks måneder gammel jente ble henvist til hudpoliklinikken fra en privatpraktiserende hudlege grunnet et raskt voksende hemangiom $i$ venstre øyevinkel. Hemangiomet var til stede som en rød makel ved fødselen, og hadde en typisk vekstfase med gradvis økende størrelse. Veksthastigheten økte da jenta var fem, måneder, med begynnende progrediering over venstre øye. Barnet var ellers friskt, med normal vekst, hun var aktiv og fikk ingen medisiner.

Ved undersøkelse ble det lagt merke til en rød elevert tumor $i$ venstre mediale øyevinkel (fig 1). Tumoren var $3 \times 3,4 \mathrm{~cm}$ stor og strakte seg opp til øyebrynet og over neseryggen, og det var begynnende vekst over venstre synsfelt. Lesjonen dekket nasale del av iris, og øyelege anmerket astigmatisme, som sannsynligvis skyldtes tumoren. De kliniske funn var forenlig med periokulært infantilt hemangiom. Det var ingen sikre holdepunkter for utvikling av amblyopi. Pasienten hadde også hemangiom i overgangen mellom høyre labia majora og peri- neum, på nedre del av abdomen og i venstre side av pannen.

MR orbita viste en velavgrenset kontrastoppladende ekspansjon, forenlig med hemangiom (fig 2). Hemangiomet hadde bred kontakt med bulbus og $\mathrm{m}$. rectus medialis med avflating av bulbus oculi. Det var ikke tegn til dyp infiltrasjon inn i orbita eller hemangiomkomponenter intrakonalt.

$P a ̊$ bakgrunn av lokalisasjonen og den raske veksten fant vi at det var indikasjon for systemisk behandling for å forhindre videre ekspansjon. Etter konferanse med barnekardiolog ble pasienten innlagt i barnemedisinsk avdeling for oppstart med propanolol. Forundersøkelsen inkluderte ekkokardiografi, med normale funn. Propanololbehandlingen ble startet med dosering $1 \mathrm{mg} /$ $\mathrm{kg} / \mathrm{dag}$ første dag og deretter $2 \mathrm{mg} / \mathrm{kg} / \mathrm{dag}$ fordelt på tre doser. Blodtrykk, puls og blodsukkernivå ble monitorert tett $i$ avdelingen de to første døgn etter oppstart.

Allerede 24 timer etter behandlingsstart ble det anmerket at hemangiomet hadde gått tilbake. Størrelsen var redusert til $2 \times 2,4 \mathrm{~cm}$ innen 48 timer. Etter to døgn kunne man se conjunktiva ved mediale canthus, som tidligere ikke hadde vært synlig, og hemangiomet ble mykere og mørkere på farge.

Pasienten ble utskrevet etter tre dagers observasjon i sykehus og deretter fulgt opp med månedlige kontroller hos hudlege og barnekardiolog. Hun tolererte behandlingen godt, var aktiv og i god allmenntilstand. Ved kontroll etter to uker påpekte moren at hun ved et par anledninger hadde vært noe mer slapp og mindre aktiv enn vanlig samt plaget med tørr hud. Tørrhet i huden ble behandlet med fuktighetskrem, og det var ingen bivirkninger senere i forløpet.

Størrelsen på hemangiomet var gradvis redusert for hver kontroll. Etter 22 ukers behandling ble behandlingen autoseponert en

\section{Hovedbudskap}

- Infantile hemangiomer rammer 8-12\% av småbarna

- I flere artikler er det rapportert effekt av propanolol i behandling av infantile hemangiomer

- Hos vår pasient med periokulært hemangiom var det rask respons på propanolol 
ukes tid. Foreldre hadde da lagt merke til tiltakende rødhet og vekst av hemangiomet. Etter 25 ukers behandling målte det 1,4×0,7 $\mathrm{cm}$ og var helt avflatet, og det var tydelig avbleking sentralt (fig 3). Tilsvarende forandringer ble sett på hemangiomene ved labia majora og abdomen. Propanolol ble seponert etter 12 måneders behandling, uten tegn til økende aktivitet $\mathrm{i}$ hemangiomet. $\mathrm{Pa}$ sienten følges videre med kliniske kontroller.

\section{Infantile hemangiomer}

Infantile hemangiomer består av klonale endoteliale celler som gjennomgår en initial vekstfase de første levemånedene. De avtar deretter vanligvis i størrelse når barnet er rundt ett år. Mekanismene som ligger bak vekstfasen er ikke fullt ut kjent. Viktige proangiogenetiske faktorer er fibroblastvekstfaktor (basic fibroblast growth factor, bFGF) og vaskulær endotelial vekstfaktor (vascular endothelial growth factor, VEGF) (1). Den påfølgende regresjonsfasen karakteriseres av apoptose histologisk.

\section{Behandlingsindikasjon}

Det er ikke påkrevd med behandling med mindre hemangiomet forstyrrer vitale funksjoner. Periokulære hemangiomer kan føre til signifikant funksjonell og kosmetisk deformitet, og mellom $43 \%$ og $50 \%$ av pasientene utvikler amblyopi (2). Systemiske kortikosteroider har vært førstevalg for systemisk behandling av hemangiomer $\mathrm{i}$ en årrekke. Interferon- $\alpha$ og vinkristin brukes sjeldnere, grunnet risikoen for henholdsvis spastisk diplegi og beinmargssuppresjon (1).

\section{Behandling med propanolol}

Leaute-Labreze og medarbeidere publiserte i 2008 en artikkel i New England Journal of Medicine der de beskrev behandling med propanolol hos 11 spedbarn i alderen 2-6 måneder med alvorlige hemangiomer (3). Hos fire av de 11 hadde man forsøkt prednisolonbehandling, uten tilstrekkelig effekt. Bakgrunnen for studien var en tilfeldig oppdagelse av rask tilbakegang av hemangiomer hos to pasienter behandlet med propanolol pga. hjertesvikt. Alle de 11 responderte på propanolol innen 24 timer. Tidlige tegn på respons var fargeforandring fra rød til lilla og at hemangiomet ble mykere ved palpasjon. De observerte videre at hemangiomene fortsatte å gå gradvis i regresjon. Klinisk bedring ble bekreftet med ultralyd hos fem av pasientene, med en objektiv reduksjon i tykkelse på hemangiomene. Pasientene ble behandlet med propanolol $1 \mathrm{mg} / \mathrm{kg} /$ dag første dag, deretter $2 \mathrm{mg} / \mathrm{kg} /$ dag fordelt på tre doser i 4-12 måneder.

Theletsane og medarbeidere rapporterte 2009 sykehistorien til et to uker gammelt barn med store hemangiomer på leppe, ører og hals (4). Barnet responderte ikke på fire ukers behandling med høydose prednisolon og utviklet gradvis øvre luftveisobstruksjon. Propanolol $2 \mathrm{mg} / \mathrm{kg} / \mathrm{dag}$ ble startet som adjuvant behandling. Tydelig regresjon og tilbakegang av stridor ble observert innen 24 timer. Prednisolon ble seponert etter 14 dager og barnet behandlet videre med propanolol som monoterapi. Alle hudforandringer var tilhelet innen seks måneder, men med arrdanning som sekvele. Flere tilsvarende kasustikker er publisert (5).

\section{Bivirkninger}

De vanligste bivirkningene av propanolol er bradykardi, hypotensjon og hypoglykemi. Siegfried og medarbeidere har nylig påpekt viktigheten av monitorering under behandlingen (6). De anbefaler ekkokardiografi før behandlingsstart og monitorering av vitale tegn og blodsukkernivå de første 48 timene. Videre anbefaler de dosering med propanolol hver åttende time, med en initial dose på $0,16 \mathrm{mg} / \mathrm{kg}$. Hvis de vitale tegn og serumglukosenivået holder seg normalt, økes dosen gradvis til vedlikeholdsbehandling maksimalt $0,67 \mathrm{mg} / \mathrm{kg} /$ dose, som tilsvarer $2 \mathrm{mg} / \mathrm{kg} / \mathrm{dag}$. De påpekte også at propanolol bør seponeres gradvis over en toukersperiode.

\section{Mekanismen bak propanololbehandling}

Mekanismen bak den gunstige virkningen av propanolol ved infantile hemangiomer er fortsatt ikke kjent. Man tror den raske initiale effekten skyldes vasokonstriksjon. Det spekuleres videre om propanolol reduserer ekspresjonen av $V E G F$ - og $b F G F$-genene gjennom å nedregulere den RAF-mitogenaktiviserte proteinkinasebanen (RAF-mitogen-activated protein kinase pathway) (1, 7). Dette kan forklare den gradvise bedringen av hemangiomet over tid. Propanolol kan videre promotere apoptose av kapillære endoteliale celler (8)

\section{Diskusjon}

Periokulære hemangiomer innebærer høy risiko for komplikasjoner (9). Behandling bør settes i gang tidlig før synsaffeksjon og amblyopi utvikles (10). Vi valgte å gi propanolol til vår pasient på bakgrunn overnevnte artikler og fordi vi anser at midlet har en bedre sikkerhetsprofil enn prednisolon. Foreldrene samtykket $\mathrm{i}$ behandlingen.

Den observerte effekten kom raskt og var på linje med hva andre har erfart. Det som er publisert, er basert på observasjon av små pasientgrupper som ikke er behandlet i prospektive, kontrollerte studier. Hemangiomets lokalisasjon og størrelse, årsak til intervensjonen, tidligere behandling og alder har variert. Det foreligger således ingen standardkriterier for å vurdere respons og for monitorering av toksisitet. Det er behov for kontrollerte studier for å dokumentere optimal dosering, monitorering, bivirkninger og varighet av behandling.

Ved bruk av propanolol bør behandlende lege alltid være oppdatert på de nyeste retningslinjene. Et annet viktig spørsmål er hvilke farmakologiske mekanismer som lig-

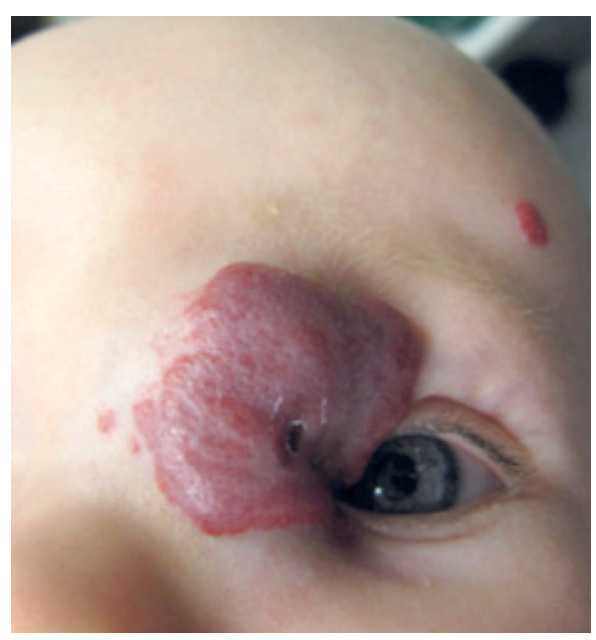

Figur 1 Hemangiomet før behandling

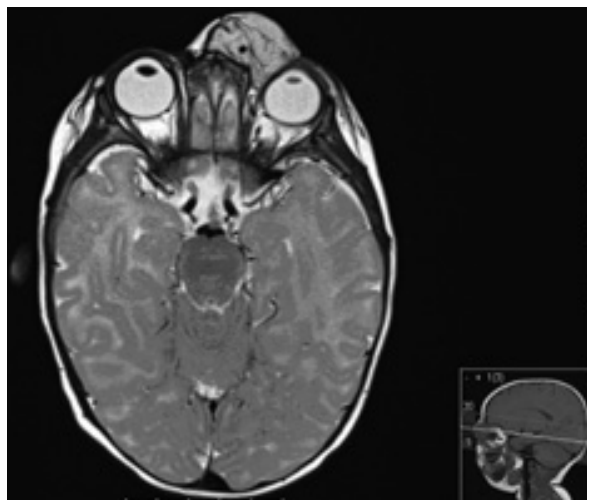

Figur 2 MR orbita før behandling - hemangiomet og avflating av bulbus oculi

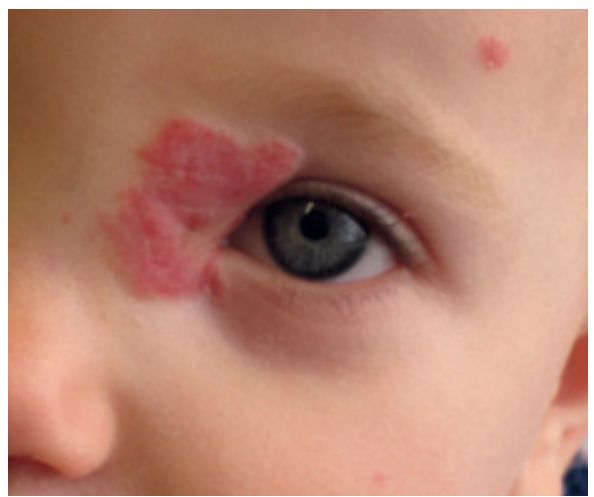

Figur 3 Hemangiomet etter 25 ukers behandling med propanolol

ger bak midlets effekt og hva det kan fortelle oss om patogenesen ved infantile hemangiomer.

Pasientens foresatte har gitt samtykke til at artikkelen og bildene av barnet blir publisert.

Oppgitte interessekonflikter: Ingen

\section{Litteratur}

1. Sundine MJ, Wirth GA. Hemangiomas: an overview. Clini Pediatr (Phila). 2007; 46: 206-21. 
2. Nguyen J, Fay A. Pharmacologic therapy for periocular infantile hemangiomas: a review of the literature. Semin Ophthalmol 2009; 24: 178-84.

3. Leaute-Labreze C, Dumas de la Roque E, Hubiche $T$ et al. Propanolol for severe hemangiomas of infancy. N Engl J Med 2008; 358: 2649-51.

4. Theletsane T, Redfern A, Raynham 0 et al. Lifethreatening infantile haemangioma: a dramatic response to propanolol. J Eur Acad Dermatol Venerol 2009; 23: 1465-6.

5. Denoyelle F, Leboulanger N, Enjolras 0 et al. Role of propanolol in the therapeutic strategy of infantile laryngotracheal hemangioma. Int J Pedatr Otorhinololaryngol 2009: 73: 1168-72

6. Siegfried EC, Keenan WJ, Al-Jureidini S. More on propanolol for hemangiomas of infancy. N Engl J Med 2008; 359: 2846; author reply 2846-7.

7. D'Angelo G, Lee H, Weiner RI. cAMP-Dependent protein kinase inhibits the mitogenic action of vascular endothelial growth factor and fibroblast growth factor in capillary endothelial cells by blocking raf activation. J Cell Biochem 1997; 67: $353-66$.

8. Sommers Smith SK, Smith DM. Beta blockade induces apoptosis in cultured capillary endothelial cells. In Vitro Cell Dev Biol Anim 2002; 38: 298-304.

9. Haik BG, Jakobiec FA, Ellsworth RM et al. Capillary hemangioma of the lids and orbit: an analysis of the clinical features and therapeutic results in 101 cases. Ophthalmology 1979; 86: 760-92.
10. Frieden IJ, Haggstrom AN, Drolet BA et al. Infantile hemangiomas: current knowledge, future directions. Proceedings of a research workshop on infantile hemangiomas, April 7-9, 2005, Bethesda, Maryland, USA. Pediatr Dermatol 2005; 22 383-406.

Manuskriptet ble mottatt 3.12. 2009 og godkjent 17.6. 2010. Medisinsk redaktør Michael Bretthauer. 